CHAPTER I

\title{
'Once upon a time would not prove to be All-time or even a long time.' From Sanitary Reform to Cultural Memory: The Case of Jacob's Island
}

\author{
Joanna Hofer-Robinson, University College Cork
}

Repurposed 19th-century warehouses, mid-20th-century social housing, and 21st-century flats and offices now occupy Jacob's Island: the site that Charles Dickens describes in Oliver Twist (1837-39) as 'the filthiest, the strangest, the most extraordinary of the many localities that are hidden in London' (416). Even the topography has changed. The tidal waterways that previously surrounded the district have been filled in. ${ }^{1}$ One accessed the site by crossing rickety wooden bridges, and, once inside, streams and canals further crosssectioned this 'small but densely populated place' (Lees Bell 36). The inlets from the Thames formerly served an industry of watermills, but, by the time that Dickens made Jacob's Island the setting for Bill Sikes's death, these waterways had become open sewers that received the inhabitants' household waste and effluvia. ${ }^{2}$ It is also likely that the water would have been contaminated by adjacent tanneries. ${ }^{3}$ At the very least, the use of manure during the manufacture of leather would have exacerbated its already malodorous conditions.

How to cite this book chapter:

Hofer-Robinson, J. 2020. 'Once upon a time would not prove to be All-time or even a long time.' From Sanitary Reform to Cultural Memory: The Case of Jacob’s Island. In: Bell, E. (ed.), Dickens After Dickens, pp. 15-34. York: White Rose University Press. DOI: https://doi.org/10.22599/DickensAfterDickens.b. Licence, apart from specified exceptions: CC BY-NC 4.0 
Off the beaten track, and long neglected by civic bodies, Dickens even claims that Jacob's Island is 'wholly unknown, even by name, to the great mass of [London's] inhabitants' (OT 416).

Jacob's Island was far from obscure by the mid-19th century, however. During the 1840s the district was repeatedly investigated by social explorers, and by the 1850 s it had been invested with an almost symbolic significance in parliamentary and committee debates about metropolitan sanitary reform. Lord Ashley (later Shaftsbury) singled out Jacob's Island in a discussion about the 'Sanitary State of the Metropolis' in 1852, for instance, calling it a 'famous place ... of a most disgusting description' (1292). In the popular press, too, references to Jacob's Island connoted dangerously insanitary conditions. For, having been linked to outbreaks of cholera in 1832 and 1848, and named 'the very capital of cholera' by Henry Mayhew ('A Visit to the Cholera Districts of Bermondsey' 4), Jacob's Island represented a threat to London as a whole. Although how disease spread was still improperly understood, leading sanitary reformers, such as Edwin Chadwick, stressed that improving urban living conditions was vital to successfully combatting public health issues associated with poor sanitation and contaminated water. It is easy to see why Dickens's description of Jacob's Island was pertinent to such concerns. Oliver Twist anticipates the currents of the mid-century sanitary movement in its stress on the area's 'confined' living quarters, 'tainted' air, and the 'muddy ditch[es]' from which the inhabitants 'haul the[ir] water up' (417). The site's notoriety was thus reinforced by fiction and non-fiction alike, and campaigns for its reform frequently comingle references to both creative and apparently factual writing.

Dickens's description of Jacob's Island is regularly quoted in articles arguing for the area's 'improvement' - the term commonly applied to large-scale urban redevelopment in the 19th century, which often included mass demolitions to clear slum housing or build new infrastructure. In an article exploring 'Modern Bermondsey' in 1842, for instance, George Dodd quotes from Oliver Twist at length. In the novel, he asserts, 'the features which this spot presents are described so vividly, and with such close accuracy, that we cannot do better than quote the passage' (20). As I will go on to explore, Dodd - as well as other writers and campaigners - evoked Oliver Twist to substantiate and reinforce his own criticisms of the area's insanitary state. Dickens's impact on the perceived identity of Jacob's Island was considerable. The Rev. W. Lees Bell's later History of Bermondsey (1880) even opined that Oliver Twist had spurred a groundswell of concern that drove the site's redevelopment to almost as significant a degree as the cholera outbreak: ${ }^{4}$

what popular writers and newspaper articles could not do the Cholera did, and in 1850 the crazy houses were pulled down, the ditches or canals filled up, and the Mill Stream and Neckinger arched over. (42-3)

Lees Bell is right to note that the version of this area provided by 'the pen of Dickens' dominated the site's popular representation both prior to initial improvements made in 1850 and after its demolition (40). Sanitary reforms 
were made in Jacob's Island in a piecemeal fashion: the tidal ditches were gradually filled in, and dilapidated housing was eventually torn down and replaced by warehouses. Even as the city changed, however, the same passage from Oliver Twist was quoted repeatedly in subsequent descriptions. ${ }^{5}$ These literary afterlives reveal ongoing intersections between written representation and the material processes of urban redevelopment, as both Dickens's novel and other writers' accounts (especially Mayhew's famous exposé for the Morning Chronicle) were recalled and reprinted throughout the area's improvement.

Even though Oliver Twist was used as a rhetorical tool to argue for the site's redevelopment from the 1840 s to the 1860 s, the text quickly ceased to be treated as an urgent call for sanitary reform thereafter. As early as the 1870 s, press commentators responded to the area's physical alteration and evoked Oliver Twist as a record of a bygone city. By the 1880s, artists and writers nostalgically reimagined Dickens's account of the site in an urban picturesque mode. Then, in the 20th century, another mass redevelopment of the area triggered more wistful yearning for Dickens's London. Consequently, as this chapter will argue, we can trace Dickensian afterlives both in the cultural processes by which the history of Jacob's Island has been constructed and in the processes which drove its material destruction earlier in the 19th century.

Dickensian afterlives can take many different forms, as the subsequent chapters in this volume will show: adaptations in different media; quotations or allusions to Dickens in other works; images inspired by his stories or characters; material culture; heritage sites; guided walks; and so on. Today, it is easiest to locate the material afterlives of Dickens's fiction in the preservation of historic buildings, ${ }^{6}$ or in retrospective reimaginings of the built environment through heritage trails or Dickensian street names. However, what this chapter suggests, and I have argued in Dickens and Demolition in greater depth, is that Dickensian afterlives are traceable in what is missing, as well as what is created or preserved. As I will go on to show, Oliver Twist was repeatedly used in campaigns for sanitary reform in Jacob's Island, which was effected, in part, by demolishing outdated buildings. By locating Dickens's material legacy in areas of London that have been demolished, as well as those that have been preserved, this chapter emphasises how imaginative worlds linger in physical spaces in unexpected, practical ways, and in so doing extend the parameters of what we conceive as literary afterlives.

Tracing Dickensian afterlives makes it possible to see processes through which cultural memories about Jacob's Island have been constructed. The concept of cultural memory is a means of analysing how stories about the past are created, disseminated, and accepted as a shared cultural heritage. We discern the significance of Oliver Twist to cultural memories of Jacob's Island because it was repeatedly evoked as a representation of the area's past across multiple media and fora. Nonetheless, while literary afterlives are frequently used to implant a sense of a common history or cultural heritage, ${ }^{7}$ the different ways that texts are reimagined in multiple media means that literary afterlives simultaneously 
reveal these cultural memories are far from stable. As Anne Rigney puts it, ' $\mathrm{t}$ ] hese memory sites are not fixed entities or finished products ... but rather imaginative resources for generating new meanings and contesting old ones' (19). The different ways in which the same passage from Oliver Twist was reimagined to portray a specific place gives textual form to these cultural processes. Conversely, the fact that the novel was also frequently evoked in arguments for its material improvement earlier in the 19th century changes the stakes in its later historicisation. In fact, the tracking of Dickensian afterlives reveals how literary narratives have been used to obscure the social impact of urban developments both during and after its improvement.

Dickens's writing was central to the reappraisal of Jacob's Island as a lost relic of a former time, just as it had been to arguments for the site's demolition. Indeed, its identity was reimagined so rapidly that there were temporal and imaginative overlaps between appropriations that used Oliver Twist to argue for contemporary urban reforms and those that evoked the same passage as a historical reference point. Moreover, imaginative reappraisals of Jacob's Island as a historical relic were published before its material redevelopment was complete. In locating and analysing Dickensian afterlives at each stage of the area's progress - from being defined as a contemporary problem site to one which inspired nostalgic sentiment - this chapter explores the role of literature in negotiating contemporary social anxieties connected with slums, but then moves on to examine its part in narrating, manipulating, and eclipsing the cultural and social histories of Jacob's Island and its communities. Where demolished sites that have been (and still are) commonly associated with, and represented through, Dickens's works - like Jacob's Island - Dickensian simulacra have come to stand for their cultural history and displaced inhabitants. It is difficult to find traces of the actual people who lived in these slum areas, but Dickensian afterlives survive in abundance. Despite Dickens's reputation as the champion of the urban poor, the ways that Dickensian afterlives have been used to campaign for and then historicise metropolitan improvements implicate his work first in displacing members of London's poor population (when the areas they lived in were redeveloped), and then in obscuring these people from view, as their living memories are veiled by literary characters and imagery. The material and social afterlives of Dickens's fiction in the case of Jacob's Island are thus opposite to his vision for greater social equality in London.

\section{Demolishing Jacob's Island}

From the early 1840 s on, Dickens was widely credited with alerting the reading public to the existence of Jacob's Island. Other writers regularly quote and allude to Oliver Twist in their accounts of the district. Dodd even remarks on the significance of Dickens's description to public images of the area: 
All Londoners have heard of the 'Rookery', or, more irreverently, the 'Holy Land' of St. Giles's; ... [but] far less is known of 'Jacob's Island' in Bermondsey, though it has been rendered familiar to many by the most successful of living novelists. (20)

Dickens's representation of Jacob's Island was certainly well known by the time Dodd published his article 'Modern Bermondsey' in 1842, but Oliver Twist was in fact preceded by Robert Wilkinson's Londina Illustrata (1819). Wilkinson's book offers an engraving showing a 'South View of London Street, Dockhead, in the Water Side Division of the Parish of St Mary Magdalen Bermondsey. SURREY' (n.pag.), alongside a map of the district. The scene is dilapidated and follows an illustration of buildings that were about to be demolished in the Strand. The condition of Jacob's Island and its position in the volume thus indicate that similar destruction is predicted in London Street. In juxtaposing these images, Wilkinson presents both scenes as records of London's past. As early as 1819 , therefore, the place was interpreted as a relic of Old London and drawn in a style that anticipates the Illustrated London News's picturesque representation of urban demolitions in the $1850 \mathrm{~s}$ and $60 \mathrm{~s} .{ }^{8}$ However, the impact that Londina Illustrata had on how Jacob's Island was popularly perceived appears to have been limited. The book is a hefty, richly illustrated tome, beyond the means of many readers. Oliver Twist was a more useful point of reference for midcentury social explorers. Aside from the novel's popular appeal, which allowed later users to mine the story for widely recognisable representational tools, its pertinence to current sanitary concerns in the 1840 s meant that it was evoked as commentary on contemporary London, rather than a record of its past.

Dodd presents Oliver Twist as evidence that supports his call for sanitary reform in Jacob's Island. His narrative is framed as a walk around Bermondsey and maps his route by recounting street names and landmarks. Titled 'Modern Bermondsey', Dodd celebrates the area's industrial progress by describing the variety and vitality of trades and manufactures based in the district. His criticism of Jacob's Island is thereby accentuated because its degenerated conditions are in close proximity to thriving industries. Dodd's meticulously observed portrayal is purportedly taken from the objective standpoint of a strolling visitor to the district. He affects a disinterested tone and foregrounds his critical praxis by evaluating the conclusions he draws from first-hand observation against secondary sources. One of these is Oliver Twist. Reading Dickens is presented as part of Dodd's wider research, and so the novel is presented as giving a faithful and realistic depiction of contemporary London. 'This is the scene', he attests, inbetween quoting long extracts from the novel (Dodd 20). Dodd's selfrepresentation as a first-hand observer indicates that quoting from Oliver Twist was less an attempt to enliven his own writing than to corroborate his claims. Fiction is represented as urban reportage - an interpretation that Dodd substantiates by comparing it to other accounts. He notes its similarity to the 'view 
of this spot' given in Londina Illustrata, for example: 'the interval of time does not seem to have produced much change in the appearance of the scene' (Dodd 21). In fact, Wilkinson's antiquarianism is distinct from Dodd's and Dickens's portrayal of Jacob's Island as a modern problem site. Nevertheless, reference to multiple texts allows Dodd to cast Oliver Twist as part of his wider critical analysis of the district, so justifying its significance to his investigations.

In 1846, Angus B. Reach affected a similarly analytical approach in London Penetralia, but aligned Oliver Twist even more explicitly with contemporary arguments for sanitary reform than Dodd had done four years earlier. Reach vociferously criticises the fact that local government bodies tolerate the insanitary conditions in Jacob's Island. In particular, he draws the reader's attention to the dangerously polluted water that inhabitants are forced to drink: 'It required a little screwing up, but we tasted the loathsome fluid. Earthy, nauseously mawkish, its savour was of the sepulchre' (Reach 14). Reach's ingestion of the water has a shocking and repulsive effect, as it prompts the reader to imagine what other substances are dissolved in the liquid. Yet, despite his avowed commitment to first-hand research and an evident desire to shock, Reach still supports his claims by quoting long extracts from Oliver Twist. Perhaps he was merely attempting to ride on Dickens's coattails by associating his writing with such a popular author. Although Dodd was a reasonably successful journeyman writer, ${ }^{9}$ Reach struggled to make a living despite working 'sixteen hours a day as a shorthand reporter, comic writer, and novelist' (Douglas-Fairhurst 144). Nevertheless, Reach's self-construction as a social explorer in turn presents London Penetralia as a critique of contemporary metropolitan conditions. Dickens's writing was thus repeatedly re-presented as urban reportage, to supplement and authenticate later writers' apparently first-hand research.

In Oliver Twist, Dickens layers topographic and social description with sensational details that heighten the narrative tension of this climactic scene. Jacob's Island is the setting for Sikes's attempted escape. It is portrayed as a pestiferous slum, and so is dangerous both because of its insanitary conditions and because it shelters a community of desperate criminals: 'They must have powerful motives for a secret residence, or be reduced to a destitute condition indeed, who seek a refuge in Jacob's Island' (OT 418). The distance between Jacob's Island and wealthier areas in London is thereby presented as both geographic and social. 'To reach this place,' Dickens's narrator explains, 'the visitor has to penetrate through a maze of close, narrow, and muddy streets, thronged by the roughest and poorest of water-side people, and devoted to the traffic they may be supposed to occasion' (416). The terrain and its populace appear to obstruct easy access. Sikes's retreat to Jacob's Island makes his capture more unlikely, and so increases the reader's sense of danger and suspense. Dickens further emphasises the site's difference to other urban spaces by amassing negative superlative adjectives in his account. In the first paragraph alone, Jacob's Island is labelled the 'dirtiest', 'blackest', 'filthiest', 'strangest', and 'most extraordinary' of London's 'hidden' localities (416). While Oliver Twist certainly presents a vivid portrayal 
of the site's insanitary conditions, therefore, the topography of Jacob's Island also contributes to building narrative tension - something which Dodd and Reach downplay.

In representing Oliver Twist as a detailed exploration of contemporary slum conditions, Dodd and Reach construct Dickens's identity as an expert on contemporary London: a persona pertinent to the mid-century public health movement. As Lauren Goodlad argues, in the early stages of the sanitary movement, a version of the public servant emerged that was 'part hero, part expert', whose 'credentials were predicated on zealous dedication to a social cause and, consequently, on unique and hard-won expertise' (536). These figures were quickly superseded by 'the public school and Oxbridge educated professional' (Goodlad 536); however, Dickens's characterisation as a specialist by the social explorers of the 1840 s overlaps with the period in which such men were influential drivers of large-scale urban improvements. Aside from outbreaks of epidemic diseases, Edwin Chadwick's 1842 Report on the Sanitary Condition of the Labouring Population of Great Britain was another significant factor in focusing public attention on sanitary reform in the $1840 \mathrm{~s} .{ }^{10}$ Chadwick was both a public servant and an indefatigable advocate of sanitary reform, who made recommendations based on substantial research. The Report envisions systematic assaults on public health problems through practical measures, such as a mass sewerage system to remove noxious waste (Goodlad 531). Metropolitan sewage disposal was not centralised until after the Metropolitan Board of Works was established in 1855, but Chadwick's report contributed to changing public policy about who should be given the authority to plan and implement such measures. The professionalism that social explorers attribute to Dickens suggestively positions imaginative writing in dialogue with official reports that investigated the modern city and made authoritative recommendations for its improvement. Reach even went so far as to say that Jacob's Island was unknown to many Londoners prior to Dickens's account: 'It's [sic] name is not even laid down in London maps. Until the appearance of a work of fiction some years ago, probably not one Londoner in ten thousand had ever read or heard of Jacob's Island' (12). ${ }^{11}$ Reach's assertion that Oliver Twist had been useful in mapping modern London aligns Dickens's novel with non-fiction documents that sought to measure and account for contemporary conditions through statistics or cartography. ${ }^{12}$ Nevertheless, even though Reach reinforces his critiques of urban conditions by allying his work with Dickens's supposedly expert insight, the name London Penetralia - meaning London's 'secret parts' or 'mysteries' (Oxford English Dictionary) - simultaneously evokes a titillating affect. Similarly to Dickens himself, these social investigators explored the pleasures that slum tourism generates for wealthier readers, as well as exposing social injustice.

As in Oliver Twist, Dodd's and Reach's accounts layer apparently objective and sensational details. While both quote from the novel as a faithful portrayal of the district, they also take cues from Dickens's emotive vocabulary. 
In addition to republishing long extracts, Dodd's own commentary patterns Dickens's dramatic model of urban description. Depicting Jacob's Island 'in all its ragged glory', Dodd draws readers' attention to 'mean and dilapidated houses' and 'small, crazy, and very primitive wooden bridges' (20). This reinforces the details given in the novel. Oliver Twist also emphasises the cramped, dirty and dilapidated condition of the built environment: 'rooms so small, so filthy, so confined ... dirt-besmeared walls and decaying foundations' (417). Dodd even directly mimics some of Dickens's more emphatic adjectival choices. For example, Dodd's use of the word 'crazy' to describe the ramshackle wooden bridges follows Dickens's description of ' [c] razy wooden galleries' (OT 417). In contrast to the formal tone and careful diction he employs to describe Bermondsey's industries, his account adopts a sensational tenor when he enters Jacob's Island. Consequently, he presents the site's obscurity as intriguing as well as dangerous. Reach also draws on the novel by employing comparable diction ('crazy' features again) and laying emphasis on similar features of the scene:

Crazy wooden galleries common to the backs of half-a-dozen houses, with holes from which to look upon the slime beneath; ... wooden chambers thrusting themselves out above the mud and threatening to fall into it - as some have done .... (OT 417)

Imagine this pestilential ditch bounded, and its reeking banks formed by a long succession of picturesque wooden dwellings, old, crazy, crumbling, in some places leaning heavily over the mud, in others settling down bodily into it. (London Penetralia 12)

Dodd and Reach give a low profile to the topography's narrative role when they refer to Dickens's novel as a form of urban investigative journalism. However, corollaries between their accounts and Dickens's description reveal that these later social explorers still sought to satisfy readers' tastes for sensational criminal scenes, at the same time as providing hard-hitting information about contemporary conditions.

In contrast to Dodd's and Reach's earlier studies, Dickens is notably absent from Henry Mayhew's famous report for the Morning Chronicle (1849)..13 Unlike previous social explorers, Mayhew's decision not to refer to Oliver Twist presents his report as a different kind of urban investigation, unmediated by fiction. This is not to say that Mayhew pretended not to have textual predecessors, but rather that he constructed a different literary genealogy to Dodd and Reach. Instead of extracting passages from Dickens's novel to support and inform his representation of Jacob's Island, Mayhew only alludes to reports that were supposedly based on fact. Mayhew quotes from London Penetralia, which, like the Morning Chronicle article, argues for contemporary sanitary reform based on personal examinations of the area ${ }^{14}$ Still, Dickens is indirectly present in Mayhew's account because Reach's representation of Jacob's Island was 
informed by Oliver Twist. Dickensian afterlives in 1840s social exploration thus mean that the novel still shadows the Morning Chronicle article.

Fictional and investigative writing had a greater impact on how Jacob's Island was popularly perceived than official reports. Although ultimately the site's redevelopment was triggered by the 1848-49 cholera epidemic, the 'Report of the General Board of Health on the Epidemic Cholera of 1848 \& 1849' (1850) deals with the area south of the river more broadly than the social explorers writing in the 1840 s.

Thus estimating the intensity of the epidemic force by the amount of mortality from cholera and diarrhœa, proportionably [sic] to every 1,000 living, it appears that Rotherhithe, which was the first in the order of mortality in the late, was only the ninth in the former epidemic; Bermondsey, the second in the late, was the fourth in the former; Southwark, the third in the late, was the first in the former; and Newington, the fourth in the late, was the sixth in the former epidemic, and so on. (Ashley Cooper 'Report of the General Board of Health' 24)

Mayhew's famous article, 'A Visit to the Cholera Districts of Bermondsey', is different to the General Board of Health's report in that it specifically identifies Jacob's Island as 'the very capital of cholera' (4). Conversely, the report indicates that Bermondsey did not have the highest mortality rate during the 1848-49 epidemic. While the report corroborates Mayhew's claim that death tolls in the area were high, Jacob's Island was not the centre point of the cholera outbreak that he suggests. Nevertheless, his article, and those of other social explorers from whom Mayhew quoted, certainly contributed to calls for sanitary reform in the district at a time when public anxieties were focused by fears about cholera and other deadly diseases. This is measurable in the fact that, by the 1850s, Jacob's Island was repeatedly evoked in parliament to advocate public health measures, such as the Metropolis Water Act (1852), which legislated for the increased provision of clean water in London. ${ }^{15}$ Jacob's Island remained an exemplar of poor sanitation even after material reforms began in 1850 .

\section{Reimagining Jacob’s Island}

The role that Dickensian afterlives performed in later representations of Jacob's Island changed when the social issues associated with the place appeared less pressing. Prior to the 1870s, Dickens's description of Jacob's Island had been repurposed as evidence of urgently needed sanitary improvements. After his death in 1870, however, Dickens's London was reimagined as a version of a bygone city with astonishing rapidity, and while the material redevelopment of Jacob's Island was still incomplete. 
The speed with which Dickens's London was reconceived is revealed by the fact that, in the early 1870s, afterlives that asserted Oliver Twist's contemporary applicability to sanitary reform overlapped, even interacted, with appropriations of the text as a historical record. In 1872, only two years after Dickens's death, the Ragged School Union Magazine published an article in which his description of Jacob's Island was used to evoke its past, earlier redevelopment and current conditions, within the same piece. Describing the changes that had occurred in the area over the past two decades, the article states that:

The foul ditch, a creek of the Thames, has been filled up, and no longer pollutes soul and body. Huge warehouses have replaced the hovels of burglars; ... The poor no longer drink the filthy, unfiltered creek-water, for most houses have the water laid on; though the less that is said about the state of the water butts the better. As might have been expected, the moral aspect of Jacob's Island has so changed that the Bill Sikeses would scarcely choose it now for a place of refuge. (35-6)

In reprinting Dickens's description as a historical account, the Ragged School Union Magazine draws readers' attention to material changes to Jacob's Island. The novel has historical value, according to the article, because of its dissimilarity to the current physical space. Oliver Twist thus allows the writer to construct a legible representation of the site's transformation by measuring the scale and success of the area's redevelopment in comparison to Dickens's fictionalised portrayal. The modern built environment is conceived alongside and through the simultaneous evocation of its past and its fictionalisation. However, Dickensian afterlives also serve a symbolic function, and defy and unsettle the specific spatial and temporal parameters implied by the article's representation of the changing built environment. The plural 'Sikeses' in the above quotation suggests, for example, that Dickens's characters personify wider and ongoing social problems, such as crime. In this, characters are severed from the specific historicisation against which, the article proposes, readers should interpret Dickens's descriptions of London places.

Multiple temporalities and fiction intersect and overlap in the Ragged School Union Magazine's representation of Jacob's Island, but the article goes so far as to argue that there are also reciprocal pathways of exchange between fictional representation and material change. Similarly to earlier commentators, the writer credits Dickens with alerting the public to Jacob's Island's very existence:

About a quarter of a century ago society was startled by Charles Dickens's sketch of a London 'crime garden.' So little was then known of the haunts of crime, that many believed the fact to be exaggerated. (Ragged School Union Magazine 34) 
The link between Dickens's fiction and localised improvements is conceived as both imaginative and practical. Noting that Oliver Twist had provoked and facilitated further investigations and comment, the writer traces how the fictional representation of Jacob's Island, and its significance to later sanitary campaigns, culminated in material change. For instance, the writer claims that Oliver Twist prompted philanthropists to establish the Jacob's Island Ragged School in 1855. Yet the novel is not only used to tell the story of how the Ragged School was founded, its location in the contemporary city is also mapped in relation to the novel. The 'Ragged School', we are told, was opened 'a few yards from Bill Sikes's house' (Ragged School Union Magazine 36). The location of Sikes's retreat is not named in Oliver Twist. In constructing a representation that comingles fiction with the physical space, the writer consciously embellishes her or his reading of Dickens's account to establish further connections between the novel and the modern city. The effect is that the article implies temporal and spatial continuity and development between Dickens's description and the present day, and so reinforces the assertion of Oliver Twist's significance to the area's redevelopment and the Ragged School's philanthropic activities.

Alluding to Oliver Twist allows the Ragged School Union Magazine's writer to justify and explain material improvements in positive terms. She or he evokes Oliver Twist as a record of a dark and dangerous past, and as a symbolic vocabulary for certain social problems. The interventions of philanthropists and urban developers can thus be conceived as assaults upon urban disorder and disease - a narrative that obscures the negative social effects of improvement. For the former inhabitants of slum areas, demolition meant displacement. ${ }^{16}$ Tenants were given scant, if any, compensation, and little appropriate housing was built to accommodate the people who were forced from their homes. Even though slum clearances were commonly conceived as part of a creative process of necessary urban amelioration, given the inadequate supply of affordable housing for the poor, in reality slum dwellers were forced to pack even more closely into remaining tenements, and at higher rents driven by increased demand. Contrary to Dickens's reputation as champion of the urban poor, the Ragged School Union Magazine borrows Dickens's supposed authority as an urban commentator to argue for the benefits of demolishing Jacob's Island. Indeed, as in its claims that Oliver Twist inspired the Ragged School's work in the area, the article states that Oliver Twist is partially responsible for its wider topographic reform: 'Such a picture could not but lead to some improvement in the sanitary condition of Jacob's Island' (Ragged School Union Magazine 35). Written only two years after obituaries had lauded and memorialised Dickens as both a reformer and a writer, the Ragged School Union Magazine's assertion that he had an instrumental impact on changing the material and social conditions of London was not unique. For instance, in the same year that this article was published, John Forster's biography similarly claimed that, 'with only the light arms of humour and laughter, and the gentle ones of pathos and sadness, he carried cleansing and reform into ... Augean stables' (157-8). 
Throughout the course of its redevelopment, Dickensian afterlives influenced the perceived social identity of Jacob's Island by hiding its real inhabitants from view. The census that was taken closest to its initial improvements suggests that Dickens's characterisation of Jacob's Island's population as transient and nefarious was not representative. The results of the 1851 census reveal a population deeply rooted in the area. In Metcalf Court - which a later writer (H.W. Jackson) believed was the location of Sikes's last hideout - most of the dwellings were arranged into family units and almost all of the men were employed. Jacob's Island was not a waste-ground for human 'refuse' but was inhabited by the labourers and mariners of local waterside industries and their families (OT 417). Apart from Frances Price from Sussex, David Davis from South Wales and his wife, Jane Davis, from Kent, all the inhabitants of the Court were born in Bermondsey or its neighbouring parishes. There was also a wide discrepancy in the ages of the inhabitants. The youngest named was just one year old and the oldest was 77; she was not the only septuagenarian ('Bermondsey. England's Census [1851]'). As unhealthy as this district undoubtedly was, then, Dickens nonetheless seems to have described its social identity as largely criminal for dramatic effect. His misrepresentation had an effect on the population, however, as his sensational reimagining of the place was later mobilised by other commentators to argue for its improvement.

Dickens critiques the damaging consequences that so-called creative destruction had on the poor elsewhere in his fiction and journalism. In 'On Duty with Inspector Field' (1851), for instance, Dickens angrily complains that: 'we make our New Oxford Streets, and our other new streets, never heeding, never asking, where the wretches whom we clear out, crowd' (267). Yet, contrary to his awareness of social injustices caused by demolitions, the ways that Oliver Twist was mobilised to argue for improvement reveal that Dickensian afterlives played a role in driving, or excusing, its effects. The popular images of the site that were circulated in the press and in debates about the area's conditions were constructed and mediated by people without experience of living in the district, who would almost always have been members of middle-class or wealthy social groups. In contrast, no evidence remains to suggest how the population living in Jacob's Island would have represented the district or themselves, or reacted to its improvement. Instead, these people are frequently replaced by fictional figures in later representations, which are deployed to reinforce the area's perceived criminal and destitute identity - as in the Ragged School Union Magazine's reference to the 'Bill Sikeses' who had previously sought refuge there. This not only appears to justify the necessity of demolitions but also disassociates their social impact from real people.

The very recently displaced residents of Jacob's Island were further dislocated from social participation or cultural history when Oliver Twist was reimagined as a representation of London's past and evoked as a carrier of cultural memories. Drawing on Pierre Nora's influential lieux de mémoire (sites of memory) concept, Astrid Erll notes that ' $[\mathrm{s}]$ ites of memory ... always point to the absence of living 
memory' (24). Indeed, analysis of how Jacob's Island was reimagined through Dickens's description and characters provides a telling example of how cultural memories can efface and eclipse certain social groups. Whether by using characters to define certain communities as Other to a magazine's target readership, or by evoking descriptive passages as exemplary accounts of a shared historical past, a Dickensian vocabulary appealed to, and helped to construct, selective collective identities. Somewhat paradoxically, such appropriations of Dickens built on the assumption that the audience of a given afterlife already recognised the author as a common cultural reference point: a supposition enabled by the popular dissemination of Dickens's works across multiple media, as much as by the fact that reference to Dickens aligns individual reading experiences with those of a wider public. Nevertheless, as in the Ragged School Union Magazine's article, later users envision an audience who survey, but do not participate in, Dickens's scenes. Their knowledge of Jacob's Island as an emblem of London's past is at one remove. By contrast, slum residents are represented as characters in the novel. They are fossilised in an idea of a Dickensian past. Consequently, Dickensian afterlives not only constructed a divisive social vision, they also created cultural memories that replaced lived experiences.

Fiction effaces living memories. There can be no living memory of Dickens's London because it is fictional. Consequently, the articulation of Jacob's Island through Dickensian afterlives effects the deliberate removal of certain social histories. It is a critical truism to say that cultural memories are as dependent on forgetting as remembering: 'In processing our experience of reality, forgetting is the rule and remembering the exception' (Erll 9). In the case of Jacob's Island, Dickensian afterlives are this exception; however, their fictional genesis signals a fracture between representations of space and lived space. This is reinforced by the fact that later commentators frequently deployed Dickensian afterlives to illustrate a contrast between the site's past and present. Literary allusion marks a break with the possibility of preserving a 'true picture of the past' - which Walter Benjamin conceives as 'flashes' that bid their 'final farewell in the moment of its recognisability' (thesis V) - rather than a means of conceptualising a historical continuum.

The cultural memories produced via Dickensian afterlives changed as further alterations to the built environment permitted Dickens's London to be nostalgically reimagined as a version of Old London. As early as the 1880s, Dickensian afterlives were produced that reconceived his portrayal of Jacob's Island in a picturesque style that emphasised its disconnectedness from modern London. In 1887, less than two decades after the writer's death, James Lawson Stewart painted a series of watercolour scenes from Dickens's novels in an urban picturesque mode. Stewart's representation of Jacob's Island both clings to and departs from Dickens's text (see Figure 1.1). Some of the details of the scene are reasonably coherent with those in Dickens's description: 'Crazy wooden galleries common to the backs of half-a-dozen houses' line a waterway faced by 'windows broken and patched' (OT 417). Stewart's painting preserves the dilapidation in Dickens's account; however, it is drawn in a comfortably picturesque 


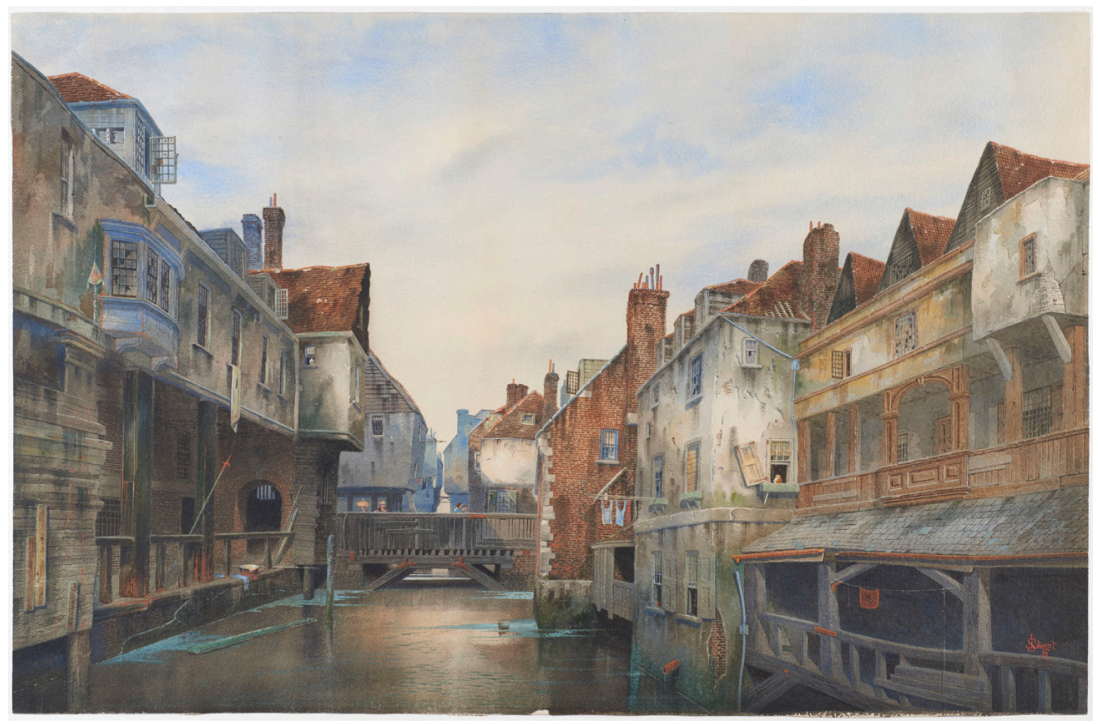

Figure 1.1: Jacob's Island, Rotherhithe, 1887 by J.L. Stewart. (c) Museum of London, reprinted with permission.

rather than a threateningly noxious style. Depicting scenes characterised by 'contrast rather than ... unity, ... irregularity rather than ... continuity, and ... the fragment rather than ... the whole' (Nead 32), Stewart's urban aesthetic follows 18 th century picturesque art. The jumbled houses are pleasantly irregular, the sepia tones are easy on the eye and the vanishing point is positioned off centre, giving a piquant unpredictability to the environment. In contrast to Dickens's account, there is no indication that the area is dangerously polluted. Strollers cross the bridge in apparently amicable conversation while another person purposefully carries goods in a basket on her head. There is even a duck swimming on the waterway. If anything, it is the duck that signals the greatest single departure from Dickens's disgust at Jacob's Island's insanitary conditions and the 'slime' and 'mud' of Folly Ditch (OT 417). Stewart's representation encourages the viewer to enjoy the scene, indicating a desire to linger in Dickens's London, like the strollers crossing the bridge in the painting.

Stewart's nostalgia conveys a sanitised vision of Old London, which eschews the dangerous connotations associated with dilapidated urban areas earlier in the 19th century. His reimagining of Dickens's scene was thereby permitted, in part, because the description in Oliver Twist no longer had a material counterpart. Like the ruins that were frequently the subject of picturesque art, the pleasure of viewing these images had to be 'at one remove' from the present, and 'softened by art' (Macaulay 454-5). In other words, the viewer's aesthetic pleasure in dilapidated urban scenes would surely have been dampened if it could be seen to threaten another cholera outbreak. By the late 1880s, Stewart 
had no need to continue to agitate for topographic or sanitary reform. The social and environmental implications of Oliver Twist, and of its afterlives up to the 1870 s, were effaced concurrently with the demolition of Jacob's Island. Stewart's nostalgic retrospective of the site and Dickens's fiction was therefore enabled by its material redevelopment.

The role Dickensian afterlives played in the construction of cultural memories was again reconceived when Jacob's Island was demolished wholesale in the early 20th century. In the 1920s, three and a half acres of south London, including Jacob's Island, were destroyed. Instead of sparking positive narratives about the site's material progress, however, newspaper reports portray the demolition as a loss, because it would erase a perceived link between the site and Dickens's novels. Their headlines include: 'London to Lose Link with Dickens', 'Dickens' “Jacob's Island” To Go', 'Where Bill Sikes Died. House to be Removed by L.C.C. Scheme of Demolition' (Press Cuttings File: Bermondsey; 'Where Bill Sikes Died' 7). Again obscuring the area's population and industries from view, these afterlives show that the imaginative association between Oliver Twist and Jacob's Island endured throughout numerous processes of material change in the district. Moreover, the impact that Oliver Twist had on how improvements were conceived is proven by the proliferation of Dickensian afterlives across multiple media and official and unofficial documents. An article in the Southwark and Bermondsey Recorder even states that Dickens's fiction was included in cartographic plans:

Some doubt has hitherto existed as to the precise position of the house where Sikes died, but all doubts have been set at rest by Mr. G. W. Mitchell, a clerk, at Bermondsey Town Hall, who, when engaged on revising drainage plans at the offices of the London County Council, discovered one dated April $5^{\text {th }}, 1855$, on which was marked the house - one of the many 'cribs,' where Fagan [sic], the Jew, Bill Sikes, the robber, and their evil associates often met. ... The house was at the back of what is now No. 18, Eckett-street, then known as Edward-street, in a court named Metcalf Court, which has been swept away, and is now occupied by the stables and yard of Messrs. R. Chambers and Co., Carmen contractors. (Jackson 1)

Rediscovered during the planning of the 1920s demolitions, these drainage plans were found serendipitously but not randomly. Unfortunately, I have been unable to locate the documents within the course of my research; nevertheless, the discovery was reported in several newspapers, including The Times ('Where Bill Sikes Died' 7). The remediation of Oliver Twist across these numerous contexts and channels shows that fiction was enmeshed in dialectical relations with how the city was conceived. Moreover, given that the exact location of Sikes's death is not named in the novel, Dickensian afterlives extend what details are made available in the text, and so continue to revise these relations between the material and the literary. 
Even when afterlives selectively appropriate or alter the text, its various incarnations reveal that Oliver Twist has helped to define Jacob's Island's cultural identity ever since the novel was published - even though it also contributed to arguments for its demolition, which effaced the conditions it describes. By the end of the 19th century, the built environment did not contain relics of the cityscape that had inspired Dickens's representation. Warehouses replaced the crazy dwellings and the ditches were filled up. Aleida Assmann has argued, however, that passing on stories is fundamental to the way we construct cultural memories and interpret our material world.

The shattered fragments of a lost or destroyed way of life are used to authenticate stories that in turn become reference points for a new cultural memory. That places require explanation, and their relevance and meaning can only be maintained through stories that are continuously transmitted. (Assmann 292)

Dickens's significance to cultural memories of Jacob's Island is thus reinforced by the reproducibility and apparent constancy of his description, in contrast to the non-presence of the built environment he describes. Nevertheless, such uses of Dickensian afterlives also effect acts of violence, as they can manipulate how the site's previous residents are perceived, or erase them from cultural history. By contrast, literary tourism continues to reinforce Jacob's Island's association with Dickens to this day. Plaques erected in the area by Southwark Borough Council register its association with Oliver Twist and embed references to the novel in a heritage trail in the district. Tracing Dickensian afterlives about Jacob's Island thus enables us to perceive how literature still affects how we conceive and construct the past and, through this, London's contemporary built environment.

\section{Endnotes}

1 'The boundaries of this district on the West and North are St. Saviour's Dock and the Thames bank, which here begins to be called "Bermondsey Wall." On the South it is bounded by Dockhead and the road towards Rotherhithe, whilst on the east it is encircled by a tidal stream called the Neckinger' (Lees Bell 37).

2 Tales of the area's history vary, highlighting the obscurity of its past. Angus B. Reach explains in London Penetralia that monks had worked an industry of watermills on the site, part of which was later transformed into a semirural place of retreat called Cupid's Gardens, probably in the early modern period (16). However, Rev. W. Lees Bell states that 'what history it may have commences with the reign of Queen Anne' (36-7). 
${ }^{3}$ A map held in the Southwark Local History Library and Archive reveals a concentration of tanning pits located in close proximity to Jacob's Island, particularly along Long Lane and Spa Road.

4 The Reverend W. Lees Bell was vicar of the parish of Christ Church in Bermondsey. A huge increase in the population of Bermondsey in the 19th century necessitated the formation of several new parishes (Malden). Although originally in the parish of St Mary Magdalen in Bermondsey, Jacob's Island was united with some other impoverished neighbouring areas in 1848 to make the new parish of Christ Church (Lees Bell 43).

${ }^{5}$ Another reason that Dickens's description may have been able to adopt such imaginative authority in the case of Jacob's Island was because of discrepancies between other accounts. Reports detailing the area in the 19th century are generally uncertain about Jacob's Island's specific location, variously attributing it to the districts of Bermondsey or Rotherhithe.

${ }^{6}$ Ruth Richardson's recent efforts to save the Cleveland Street workhouse from redevelopment were materially assisted by her discovery of its association with Dickens (see Dickens and the Workhouse, OUP, 2012).

${ }^{7}$ In The Afterlives of Walter Scott (OUP, 2012), Rigney discusses how frequently literary names were chosen as place names in colonial territories in the 19th century. She argues that this 'was a way of implanting a sense of history in new urban environments and of nostalgically flagging a collective affiliation to an imagined history in newly settled territories' (1).

${ }^{8}$ Lynda Nead discusses the Illustrated London News's representation of urban improvements in Victorian Babylon, Yale UP, 2005: pp. 29-31.

9 Dodd wrote extensively for high-quality, popular periodicals, including 65 pieces for Household Words (see Dickens Journals Online).

${ }^{10}$ Edwin Chadwick was not the only government official to publish extensive reports. Another member of the General Board of Health (the centralised government body in charge of sanitary measures in the mid-19th century) to publish his investigations into urban sanitation was Dr Thomas Southwood Smith. Dickens supported Southwood Smith's conclusions. After reading Southwood Smith's report 'On Extramural Sepulture [sic]' (1850), for example, Dickens wrote to congratulate him on this 'monument of good sense, moderate reasoning to demonstration, and noble feeling' (Letters 6:51).

11 Searching the records of trials at the Old Bailey reveals no mention of Jacob's Island. However, specific streets in that area are named, usually in relation to crimes of theft. For instance, in March 1839 William Watson, a resident of the area, was found guilty of stealing shirts and imprisoned for six months (Old Bailey Proceedings Online). While Oliver Twist may have brought the name 'Jacob's Island' into common usage, then, the area was not as invisible to London's populace as Reach suggests.

12 In Victorian Babylon, Nead argues that 19th-century writers referred to statistical analysis in textual accounts of the city in attempts to understand 
and represent the rapidly expanding city. However, it remained difficult to comprehend the city's vastness: 'Rather than offering any numerical truth about the city ... these statistics evoked a poetic image of London as an immense open-mouthed body, consuming everything that comes within its grasp' (15).

${ }^{13}$ Mayhew does, however, quote Dickens elsewhere in London Labour and the London Poor. In 'Of Second-hand Store Shops', for instance, he refers to Dickens as 'one of the most minute and truthful of observers' (2:24).

${ }^{14}$ Intersections between Reach's and Mayhew's writings are somewhat to be expected. Mayhew's 'Visit to the Cholera Districts of Bermondsey' was written in his role as 'Metropolitan Correspondent' for the Morning Chronicle. Reach was Mayhew's colleague. The Morning Chronicle sent correspondents to enquire into the 'Condition of England' in diverse regions. Reach was correspondent for the manufacturing districts at the same time as Mayhew pursued his metropolitan investigations.

15 See, for instance, Hansard, 3rd ser., vol. 117 (5 June 1851), c. 463.

${ }^{16}$ I give a more detailed explanation of these contexts in Chapter 1 of Dickens and Demolition. Discussed here with permission from Edinburgh University Press.

\section{Works cited}

Ashley Cooper, Anthony ( $7^{\text {th }}$ Earl of Shaftsbury). 'Report of the General Board of Health on the Epidemic Cholera of 1848 \& 1849'. British Parliamentary Papers, 1850, https://parlipapers.proquest.com/parlipapers. Accessed 5 Jan. 2014.

—. 'Sanitary State of the Metropolis.' Hansard, vol. 120, 29 Apr. 1852, cc.1283 - 1315, https://hansard.parliament.uk. Accessed 7 Jan. 2014.

Assmann, Aleida. Cultural Memory and Western Civilization: Functions, Media, Archives. Cambridge UP, 2011.

Benjamin, Walter. 'On the Concept of History'. Marxists Internet Archive. Translated by Dennis Redmond, 2005, www.marxists.org/reference/archive /benjamin/1940/history.htm. Accessed 4 Apr. 2015.

'Bermondsey. England's Census (1851).' Ancestry, www.ancestry.co.uk. Accessed 16 Feb. 2013.

Dickens, Charles. Oliver Twist. Edited by Philip Horne. Penguin Books, 2009.

—. 'On Duty with Inspector Field'. Household Words, vol. 3, no. 64, 14 June 1851, pp. 265-70.

- The Letters of Charles Dickens, The Pilgrim Edition, vol. 6, 1850-1852. Edited by Graham Storey and Kathleen Tillotson. Clarendon Press, 1988.

'Dickens's 'Jacob’s Island' To Go.' 15 Feb. 1923. Southwark Local History Library and Archive, London, PC942.16413, Press Cuttings File: Bermondsey, newspaper cutting. 
Dodd, George. 'Modern Bermondsey'. London, vol. 3. Charles Knight, 1842, pp. 17-32.

Douglas-Fairhurst, Robert. Becoming Dickens: The Invention of a Novelist. The Belknap Press of Harvard UP, 2011.

Erll, Astrid. Memory in Culture. Translated by Sara B. Young. Palgrave Macmillan, 2011. [Original German language edition: Erll, Astrid. Kollektives Gedächtnis und Erinnerungskulturen. Eine Einführung. J. B. Metzlersche Verlagsbuchhandlung und Carl Ernst Poeschel Verlag $\mathrm{GmbH}, 2005$.

Forster, John. The Life of Charles Dickens, With 500 Portraits, Facsimiles and Other Illustrations, vol. 1. Edited by B. W. Matz. Chapman and Hall Ltd., 1911.

Goodlad, Lauren M. E. 'Is There a Pastor in the 'House'?: Sanitary Reform, Professionalism, and Philanthropy in Dickens's Mid-Century Fiction.' Victorian Literature and Culture, vol. 31, no. 2, 2003, pp. 525-53.

Hofer-Robinson, Joanna. Dickens and Demolition: Literary Afterlives and Mid-Nineteenth Century Urban Development. Edinburgh UP, 2018.

Jackson, H.W. Jacob's Island. Bermondsey Central Library, 1948. [First published in Southwark and Bermondsey Recorder, 24 Aug. 1917-25 Jan. 1918.] 'Jacob's Island Ragged School, Bermondsey'. Ragged School Union Magazine, Feb. 1872, pp. 34-8.

'Lair is Doomed.' Daily Mirror, 30 Apr. 1924. Southwark Local History Library and Archive, London, PC942.16413, Press Cuttings File: Bermondsey, newspaper cutting.

Lees Bell, Rev. W. The History of Bermondsey. Shaw and Sparks, 1880.

Macaulay, Rose. Pleasure of Ruins. Thames and Hudson, 1966.

Malden, H.E. 'Parishes: Bermondsey.' A History of the County of Surrey, vol. 4. Edited by H.E. Malden, 1912, pp. 17-24. British History Online, www.british-history.ac.uk. Accessed 13 Dec. 2013.

Map of Tanning Pits in the Parish of Bermondsey. 1833, map, Southwark Local History Library and Archive, London, 198, map.

Mayhew, Henry. 'A Visit to the Cholera Districts of Bermondsey' Morning Chronicle, 24939, 24 Sep. 1849, p. 4.

- London Labour and the London Poor. The London Street-Folk, vol. 2. Griffin, Bohn, and Company, 1861.

Nead, Lynda. Victorian Babylon: People Streets and Images in NineteenthCentury London. Yale UP, 2000.

Oxford English Dictionary Online, www.oed.com. Accessed 25 May 2017.

Reach, Angus B. London Penetralia. Bradbury and Evans, 1846.

Richardson, Ruth. Dickens and the Workhouse: Oliver Twist and the London Poor. Oxford UP, 2012.

Rigney, Ann. The Afterlives of Walter Scott. Oxford UP, 2012.

'Trial of WILLIAM WATSON (t18390304-966), March 1839.' Old Bailey Proceedings Online, www.oldbaileyonline.org, version 7.2. Accessed 18 Oct. 2015. 
'Where Bill Sikes Died.' The Times, 42491, 17 Aug. 1920, p. 7.

Wilkinson, Robert. Londina Illustrata. Graphic and Historic Memorials of Monasteries, Churches, Chapels, Schools, Charitable Foundations, Palaces, Halls, Courts, Processions, Places of Early Amusement and Modern and Present Theatres, in the Cities and Suburbs of London and Westminster. Robert Wilkinson, 1819. 